\title{
The Relationship between FDI Enterprise Earnings and Signs of Transfer Pricing
}

\author{
Nguyen Thanh Nguyen ${ }^{1}$ \\ ${ }^{1}$ Graduate School, Ho Chi Minh City Open University, Vietnam \\ Correspondence: Nguyen Thanh Nguyen, Graduate School, Ho Chi Minh City Open University, 97 Vo Van Tan \\ Sreet, Ward 6, District 3, Ho Chi Minh City, Vietnam. Tel: 84-9-1387-6124. E-mail: \\ thanhnguyenla57@yahoo.com; thanhnguyen@longan.gov.vn
}

Received: May 1, 2019

doi:10.5539/jsd.v12n4p99
Accepted: June 22, $2019 \quad$ Online Published: July 30, 2019

URL: https://doi.org/10.5539/jsd.v12n4p99

\begin{abstract}
This paper presents the relationship between the signs related to transfer pricing and the earnings of enterprises. This study proves that this economic phenomenon exists in Vietnam; however, transfer pricing does not cause severe harm to taxation, and foreign direct investment (FDI) enterprises still have a positive impact on the national economy.
\end{abstract}

Keywords: transfer pricing, exports, multinational corporations, FDI enterprises, earnings, tax evasion

\section{Introduction}

In developing countries, the attraction of foreign direct investment (FDI) enterprises is a way to encourage economic growth. The results of this policy undeniably have an important role in fostering socio-economic development. FDI enterprises help address the weaknesses of the economy and reduce unemployment. Statistically, many countries have successfully industrialized through strong FDI. However because of profit concerns, some of these enterprises have become involved in international transfer pricing. According to some governments, international transfer pricing can cause losses to the national income and inequality of businesses in host countries. In reality, it is difficult to determine the transfer pricing in developing countries with an incomplete legal system. Governments also cannot exactly calculate the loss of the national budget and compare the profit of the economy from FDI enterprises and their income tax loss.

In Vietnam, FDI enterprises have contributed significantly to GDP growth, unemployment reduction, and exports. According to the Vietnam General Statistics Office, in late 2015, there were 21,290 FDI projects (registered capital of US\$ 313.5 billion and performed capital of US\$ 139 billion). As stated by authorities, foreign investments have also caused national trade deficits, negative environmental impacts, and tax losses from transfer pricing. A report by the Vietnam Ministry of Finance (V.MoF.2015) showed that some FDI enterprises reported business losses while continuing to expand their operations. These phenomena reveal the possibility of fraud and tax evasion; the associated enterprises used import-export cooperation as a method of transfer pricing. However, with the current legal system, it is difficult to detect this unfair activity, and no studies determine budget losses from transfer pricing activities and compare with the national interest from FDI enterprises, especially for multinational corporations (MNCs).

As a result, it is necessary to conduct a study aiming at identifying the signs of transfer pricing and its impact on the national budget. Based on these results, the government can assess this phenomenon, apply more efficient solutions, create a fair and transparent investment environment, and limit the loss of national revenue. The study aims to reveal the relationship between signs related to transfer pricing and enterprise income statements (related to income taxes); it also proposes some advice for governments. In this analysis, the author used secondary data from 381 FDI enterprises for the 2007-2015 period (data from governmental organizations). The dependent variable is earnings before tax (EBT), with signs related to transfer pricing and enterprise performance factors as independent variables. The results prove the presence of transfer pricing and its impact on the income tax of FDI enterprises.

\section{Literature Review}

According to Andrew Lymer and John Haseldine (2002), transfer pricing is the price execution of goods, 
services, and assets transferred among divisions of an MNC. These international transactions do not observe market prices and aim to minimize the MNC's income tax. Li, J. (2005) noted that international transfer pricing is the process of pricing goods and services within an enterprise that has operations in different countries.

Jonhson and Kirsch (1991) surveyed 576 enterprises in the US and discovered that the minimization of income tax is an important target. Tang $(1981,1993)$ showed the same result; when Tang (1981) compared the factors related to transfer pricing by MNCs of Canada and England, he found that overall profit is most important. Tang (1993) studied the 500 largest industrial corporations in the US and concluded that overall profit and difference in income tax rates were the two most important factors affecting international transfer pricing. A survey by Ernst \& Young (2003) determined that $73 \%$ of examined enterprises aimed to maximize results and $68 \%$ had a tendency to minimize income tax, which is the motivation to conduct international transfer pricing. Eggert and Winner (2010) used data from 31 European countries and proved that MNCs obtain considerably higher profit than enterprises in the same business in host countries that have lower income tax rates, and vice versa. These studies determined that income tax rates are one of the most important factors that encourage transfer pricing, which affects the earnings before tax of FDI enterprises.

In addition, other factors can encourage transfer pricing. While the exchange rate is a weak cause of transfer pricing, Jensen and Schott (2006), Kim and Miller (1979), Garrison and Noreen (2000) proved that transfer pricing is employed to limit exchange risk. Opportunity cost (Eden, 2003), the inflation rate in host countries (Tang, 1981), and the economic-political environment (Easson, 1999; Chan and Chow, 1997) also promote this economic phenomenon.

According to the Vietnam Ministry of Finance's annual report on the performance of FDI enterprises, tax evasion may occur through these firms' transfer pricing activities (although they could not show data to prove this phenomenon), particularly among enterprises that engaged in import-export cooperation and featured continuously low profits or losses across many years (V. MoF. 2015).

\subsection{Objectives of Transfer Pricing}

Many conclusions have been made about the objectives of transfer pricing. Bradley (1991) found that minimizing funds, taxes, tariffs, and exchange risk; avoiding exchange controls and quotas; increasing the share of profits from joint ventures and optimizing managerial incentives are MNCs' key aims when engaging in transfer pricing. In a survey (2003), Ernst \& Young cited two main objectives of MNCs' transfer pricing: maximizing operating performance and optimizing tax arrangement.

\subsection{Methods of Transfer Pricing}

Okoye (2011) grouped transfer pricing methods into three categories: cost-based, market-based and negotiated. Choi and Mueller (1992) identified four categories: comparable uncontrolled, resale, cost-plus and other pricing methods. Meanwhile, Ezejelue (2008) classified two broad groups: traditional transaction methods and profit methods. These methods aim to maximize the profit and optimize the performance of MNC members or transaction enterprises.

\subsection{Signs of Transfer Pricing}

The Vietnam Ministry of Finance (V.MoF. 2015) issued an announcement about the signals of transfer pricing and the phenomena experienced by these enterprises: they have losses for many years but continue to expand their business, have import-export activities with parent enterprises located in countries with lower income taxes, and have lower profit ratios than other enterprises in the same business. However, the Vietnam Ministry of Finance does not affirm that all associated enterprises engage in transfer pricing. In addition, FDI enterprises also face difficulties as internal enterprises at startup.

According to the Vietnam General Department of Taxation (V.G.D.T.2011), the signs of transfer pricing by an FDI enterprise can be the following:

- The enterprise declares losses in its business over many years;

- The enterprise has transaction activities with associated enterprises from other countries that have lower income tax rates than the host country;

- The enterprise's profit situation is unusual;

- The profit of the enterprise is lower than the profit of other enterprises in its group;

- The enterprise has low production costs.

However, experts have also made other conclusions about the signs of transfer pricing among FDI enterprises: 
- The enterprise experiences severe losses over many years but continues to enlarge its business scale, and its turnover continues to grow;

- The enterprise's business performance is poor, but the firm continues to receive loans from associated enterprises, parent companies or bosses;

- The enterprise has few customers across many continuous years, and the enterprise sells its product at a price equal to the production cost;

- For the same product or service supplied by the enterprise, the selling price in the internal market is higher than the price of exportation;

- The enterprise has non-payment liabilities and receivable debts from cooperative customers but continues to do business with them;

- The enterprise's goods of transaction are from three or more countries.

In general, the signs of transfer pricing are related to enterprises' losses or earnings.

\subsection{Impact of Transfer Pricing on Enterprises and the Host Country}

Many papers study the impacts of transfer pricing on the economy. Dunning (1993) concluded that transfer pricing has an important role in MNCs' activities, which helps minimize the negative impact of inflation and fluctuation of foreign exchange rates; it also helps to achieve the long-term target of MNCs because it relates to many activities such as taxation, production, marketing, and finance policies. Vicard (2015) studied transfer pricing in France and discovered that transfer pricing activities caused a decrease in export value $(0.7 \%)$ and an increase in import value $(0.5 \%)$; this event reduced the national income tax by approximately US $\$ 8$ billion in 2008, and this reduction grew through the 2000s. Thus, FDI enterprises' declared income is lower than their actual income. In an empirical study, Eden and Rodriguez (2004) revealed that in the US, price augmentation of import goods occurred among divisions of MNCs. These studies prove that transfer pricing occurs among MNC divisions, which encourages the revision of governmental regulation to control tax evasion.

Through transfer pricing, FDI cooperation enterprises, especially divisions of MNCs, aim to lower their income tax and usually use the transactions between the divisions of MNCs or transactions the parent company to do so. In many countries, governments accept these transactions, but enterprises must respect the Arm's-Length Principle (ALP). The ALP is a principle of the OECD to control the price of goods and services of transaction partners. Transfer pricing may cause an enterprise's reported EBT to be lower than its true value.

In host countries, governments usually aim to attract MNCs to develop the economy and issue policies to attract foreign investment while maintaining acceptable side effects. However, the tax authorities of many countries usually blame FDI enterprises for tax losses that directly affect the national budget. Many critics accuse MNCs of changing the structure of national capital, causing difficulty in macroeconomic management. On the other hand, they also claim that transfer pricing triggers unfair competition and inequality among the same business enterprises of host countries (Okwoma, 2014). These criticisms seem unfair and prejudiced. In fact, FDI enterprises, especially MNCs, have changed their policies to adapt to new competitive environments. Currently, transfer pricing is not a good way to increase profits if enterprises have a smart vision for the future.

\subsection{Transfer Pricing Activities in Vietnam}

According to the Vietnam General Department of Taxation (V.G.D.T.2011), transfer pricing activities in Vietnam can occur in the following ways:

- Transfer pricing through the transaction of tangible goods: this method is the most common, where FDI enterprises trade with foreign partner enterprises (in their group). They purchase or sell goods, materials, and products with lower or higher market prices to minimize the income tax of the group (associated enterprises); this approach helps to increase the income of the group, but it causes a reported EBT that is lower than the real value.

- Transfer pricing through the transaction of intangible assets: enterprises can perform transfer pricing through activities of licensing, franchising, patenting, and sharing knowledge of production, science and technology, and human resources.

- Transfer pricing through supplying services: in this case, the parent company or associated enterprises supply or assist the service of management (finance and accountancy); then, FDI enterprises pay for these transactions. In reality, the reasonable price of these services is very difficult to determine.

According to a report by the Vietnam Ministry of Finance from 2010 to 2017, approximately 50\% of FDI 
enterprises declared losses across years, but they still maintain operation and enlarge their activities (HCM City: 45\%, Binh Duong: 47\%, Dong Nai 49\%, Long An 49\%). Many of these enterprises operate in fields of garment processing, footwear, production and exports, and processing industry. The authorities suspect that these enterprises carry out transfer pricing.

*Vietnam Coca Cola is a large FDI enterprise with an investment of US\$ 150 million. For over 20 years operating in Vietnam, they always declared losses; however, their turnover increased 20\% per year, and they planned to invest more than US\$ 300 million. Vietnam PepsiCo is similar; it continuously reported losses for two decades. In recent years, Vietnam PepsiCo has declared profitability, but the rate of profit on revenue was very low (approximately 2\%); even so, PepsiCo continued to invest in other two factories (US\$ 118 million). Another company, Keangnam Vina, reported losses of US\$ 12 million (from 2007-2011), paying loan interest of 12\% per year for Kookmean Bank and capital arrangement fees of US\$ 30 million. After inspection, this enterprise agreed to a cost reduction adjustment. In Hanoi, HCM City, Dong Nai, and Binh Duong, the Department of Taxation discovered many income tax law violations by FDI enterprises, which could be signs of transfer pricing.

\subsection{Types of FDI Enterprise Businesses Related to Transfer Pricing}

The Vietnam General Department of Taxation reports present common types of business that perform transfer pricing:

- FDI enterprises process products for exportation: these enterprises are situated outside of export processing zones, but they import almost all raw materials and export all their products to their associated enterprises. The price of import goods is usually high, while export product prices are low, so their income appears poor even when the business is at a loss.

- Enterprises manufacture goods by contract with associated enterprises: these enterprises produce products with materials (usually imported) that their partner designates at a high price and export their goods at a low price (determined in a contract).

- FDI enterprises import semi finished products from associated enterprises or parent companies and then finish these products and sell them in internal markets at high prices: In this case, FDI enterprises import machinery materials, technologies, and know-how at a higher price than market prices and then reduce the mortgage time in order to minimize the income tax.

According to Vietnamese authorities, most transfer pricing activities aim to lower income taxes, so if the FDI enterprises perform these activities, their EBT is guaranteed to be low. Transaction pricing always affects these companies' EBT.

\subsection{Data on FDI Contributions and the Vietnamese Economy}

Economists and the Vietnamese government affirm that the contribution of FDI enterprises drives the Vietnamese economy. Although these enterprises' activities have been criticized for causing an imbalance of national cash flows, environmental pollution, and tax loss from transfer pricing, for example; there is no official report on these activities' negative effect on the Vietnamese economy (except for a pollution event from the Formosa group).

In fact, FDI strongly encourages GDP growth, exportation, employment, labor productivity melioration, technology improvement, and economic restructuring. From 1990 to 2014, the FDI net inflows increased 65 times, and GDP increased 30 times (V. MoF. 2015). The contribution of FDI to GDP grew from 14\% to 23.3\% and from $5.22 \%$ to $14.18 \%$ of national revenue from 2005 to 2015 (V. MoF. 2005). In the field of exports, FDI enterprises, especially MNCs, have achieved an important role. In 2017, FDI enterprises made 72.4\% of total national exports, of which Samsung (an MNC) received one-third of these exports. FDI enterprises are big employers; they received 3.2 million workers (2013), eight times the figure from 2000. According to the report from Vietnam's labor ministry (2017), the labor productivity in FDI enterprises is now eight times higher than that of domestic enterprises. In 2016, the FDI contributed $31 \%$ of the growth of Vietnam's labor productivity. This sector also applied new technology for their investment and promoted technology innovation in Vietnam. With the strong augmentation of FDI, the economic structure changed rapidly, and after twenty years (1995-2015), Vietnam became an industrial country (the industrial and service sector achieved $83.68 \%$ of GDP). These data prove that FDI enterprises, especially MNCs, have a very important role in the development of the Vietnamese socio-economy; a negative does not appear.

\section{Hypotheses and Methodology}

Based on FDI enterprise management in Vietnam, this research proposes hypotheses to determine the relationship between the signs related to transfer pricing and enterprises' EBT (loss of the national budget). 


\subsection{Research Model and Hypotheses}

In reality, it is difficult to exactly determine an enterprise's transfer pricing. Based on secondary data for FDI enterprises, the report of Vietnam Ministry of Finance and General Statistics Office, this research studies the relationship between enterprises' earnings (EBT) and factors that relate to transfer pricing. The results of the study reveal the signs of this fraud and the level of damage caused by transfer pricing. Based on the results, the government can estimate the reality of this economic event in Vietnam.

The study proposes nine hypotheses in two groups and presents the following conceptual model (see Fig. 1):

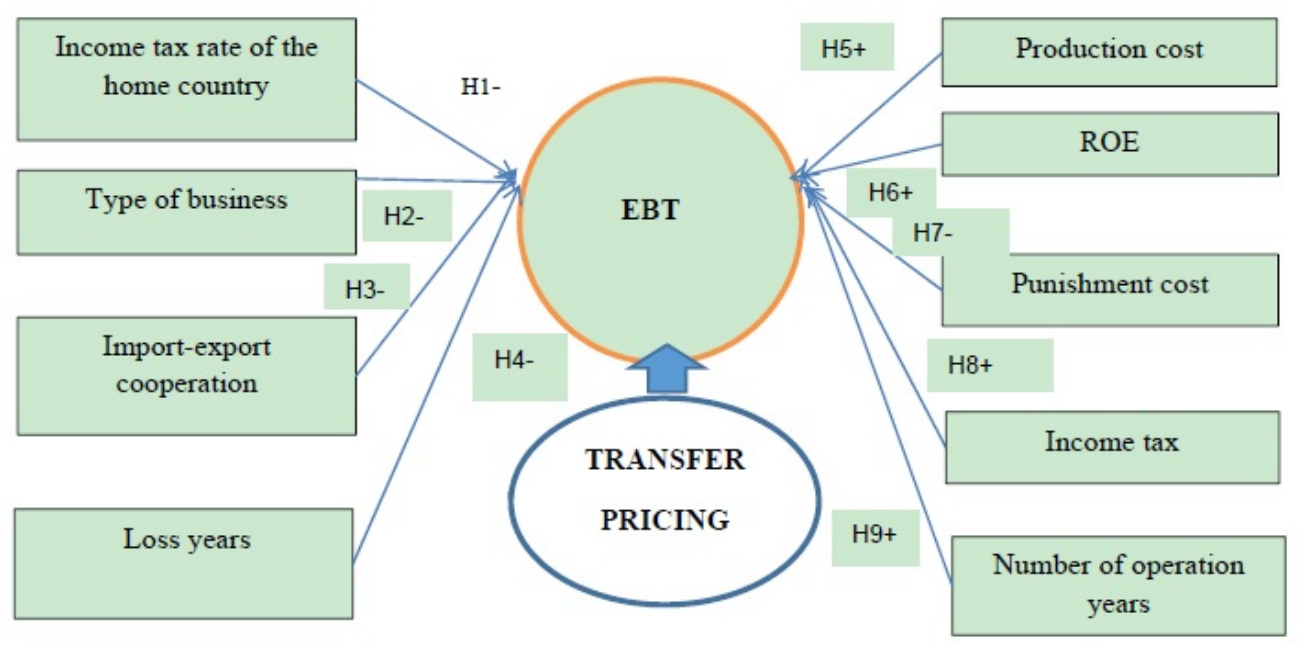

Figure 1. Conceptual model

This is a quantitative study based on secondary data from 381 FDI enterprises (2007-2015) in South Vietnam, and the author used SPSS to analyze the hypotheses. The study is presented in the following multivariable regression model:

$$
\mathrm{Y}=\beta_{0}+\beta_{1} \mathrm{X}_{1}+\beta_{2} \mathrm{X}_{2}+\ldots+\beta_{9} \mathrm{X}_{9}+\mathrm{u}, \text { where }
$$

$\mathrm{Y}$ : Dependent variable: EBT of enterprises (VND billion).

$\mathrm{X}_{\mathrm{i}}$ : Independent variable; $\beta_{\mathrm{i}}$ : coefficient; $\mathrm{u}$ : error.

$\mathrm{X}_{1}$ : Income rate of the home country ( 1 if it is greater than or equal to $22 \%$, the income tax rate of Vietnam; 0 if it is smaller than $22 \%$ ).

$\mathrm{X}_{2}$ : Business type ( 1 if the enterprise has import-export activities, 0 if it does not).

$\mathrm{X}_{3}$ : Import-export cooperation of enterprises (percentage of import-export cooperation and total import-export value).

$\mathrm{X}_{4}$ : Number of loss years.

$\mathrm{X}_{5}$ : Production cost (VND billion).

$\mathrm{X}_{6}$ : ROE (return on equity, VND billion).

$\mathrm{X}_{7}$ : Punishment cost about infringement of regulation (VND billion).

$\mathrm{X}_{8}$ : Amount of the enterprise's income tax (VND billion).

$\mathrm{X}_{9}$ : Number of years in operation.

Hypotheses (see Table 1): 
Table 1. Summary of hypotheses

\begin{tabular}{|c|c|c|c|c|}
\hline Group & Hypotheses & $\begin{array}{l}\text { Independent } \\
\text { variables }\end{array}$ & $\begin{array}{c}\text { Hypothesized } \\
\text { effect on FDI } \\
\text { enterprises' EBT }\end{array}$ & $\begin{array}{c}\text { Hypothesized } \\
\text { relationship with FDI } \\
\text { enterprises' EBT }\end{array}$ \\
\hline \multirow{4}{*}{$\begin{array}{l}\text { Signs of } \\
\text { transfer } \\
\text { pricing }\end{array}$} & $\mathrm{H}_{1}$ & $\begin{array}{l}\mathrm{X}_{1} \text {-Mother country income } \\
\text { tax rate }\end{array}$ & - & Moderate \\
\hline & $\mathrm{H}_{2}$ & $\mathrm{X}_{2}$-Business type & - & Moderate \\
\hline & $\mathrm{H}_{3}$ & $\begin{array}{l}\mathrm{X}_{3} \text {-Import-export } \\
\text { cooperation ratio }\end{array}$ & - & Moderate \\
\hline & $\mathrm{H}_{4}$ & $\mathrm{X}_{4}$-Loss years & - & Moderate \\
\hline \multirow{5}{*}{$\begin{array}{l}\text { Control } \\
\text { factors }\end{array}$} & $\mathrm{H}_{5}$ & $\mathrm{X}_{5}$-Production cost & + & Moderate \\
\hline & $\mathrm{H}_{6}$ & $\mathrm{X}_{6}-\mathrm{ROE}$ & + & Moderate \\
\hline & $\mathrm{H}_{7}$ & $\mathrm{X}_{7}$-Punishment cost & - & Moderate \\
\hline & $\mathrm{H}_{8}$ & $\mathrm{X}_{8}$-Income tax & + & Moderate \\
\hline & $\mathrm{H}_{9}$ & $\mathrm{X}_{9}$-Operation years & + & Moderate \\
\hline
\end{tabular}

- Tang (1993), Eden, L. (2004) proved that the low income tax of parent countries encourages the transfer pricing of FDI enterprises to evade taxation. In Vietnam, the income tax is rather high, so the study supposes that there is a relationship between the parent country's income tax rate and the enterprise's earnings (a sign of transfer pricing).

H1: The income tax rate of the parent country has a relationship (-) with the FDI enterprise's EBT.

- According to the Vietnam General Department of Taxation (V.G.D.T. 2011), the type of FDI enterprises that have import-export cooperation with foreign enterprises in their activities can perform transfer pricing through international processes, which impacts their EBT.

H2: The type of FDI enterprise activities has a relationship (-) with the enterprise's EBT.

- The report by the Vietnam General Department of Taxation (V.G.D.T.2011) warned that FDI enterprises that perform a high proportion of cooperation transactions in import-export activities have a probability of transfer pricing and impact their EBT.

H3: The ratio of import-export cooperation on the total value of import-export has a relationship (-) with the FDI enterprise's EBT.

- According to many financial specialists, the number of years of claimed losses has a relationship (-) with the FDI enterprise's EBT.

H4: Number of years of claimed losses has a relationship (-) with the FDI enterprise's EBT.

In addition to four variables related to transfer pricing, the study also presents five control variables.

- When enterprises develop their production, their costs increase, and their earnings usually grow.

H5: Production cost has a relationship (+) with the FDI enterprise's EBT.

- Enterprises' performance indicators always have a relationship with their earnings.

H6: ROE (return on equity) has a relationship (+) with the FDI enterprise's EBT.

- The enterprises pay more punishment fees when their activities have a bad result.

H7: Punishment cost has a relationship (-) with the FDI enterprise's EBT.

- The income tax of an enterprise is based on earnings before tax.

H8: Amount of income tax has a relationship (+) with the FDI enterprise's EBT.

- When an enterprise has a long period of operations, it is usually more stable and prosperous.

H9: The number of operation years has a relationship (+) with the FDI enterprise's EBT. 


\subsection{Research Design and Measurement Instrument}

The study used secondary data from 381 FDI enterprises in Southern Vietnam. These data consist of enterprises' activity results and come from the planning and investment departments, management offices of economic zones, tax offices, and customs offices. The study used SPSS 22.0 to investigate the correlation and estimate regression to determine the relationship between factors related to transfer pricing and the earnings of enterprises.

\section{Analysis of Findings}

\subsection{Characteristics of Studied FDI Enterprises}

The statistical data (V. MoF, 2015) show that most FDI enterprises are from Asia (87.9\%), and Taiwan, Japan, Korea, and China have the largest number of FDI enterprises in the study sample. These firms' businesses are rather diversified, but they operate mainly in processing, manufacturing, trading, and import-export activities (see Figures 2, 3, and 4).

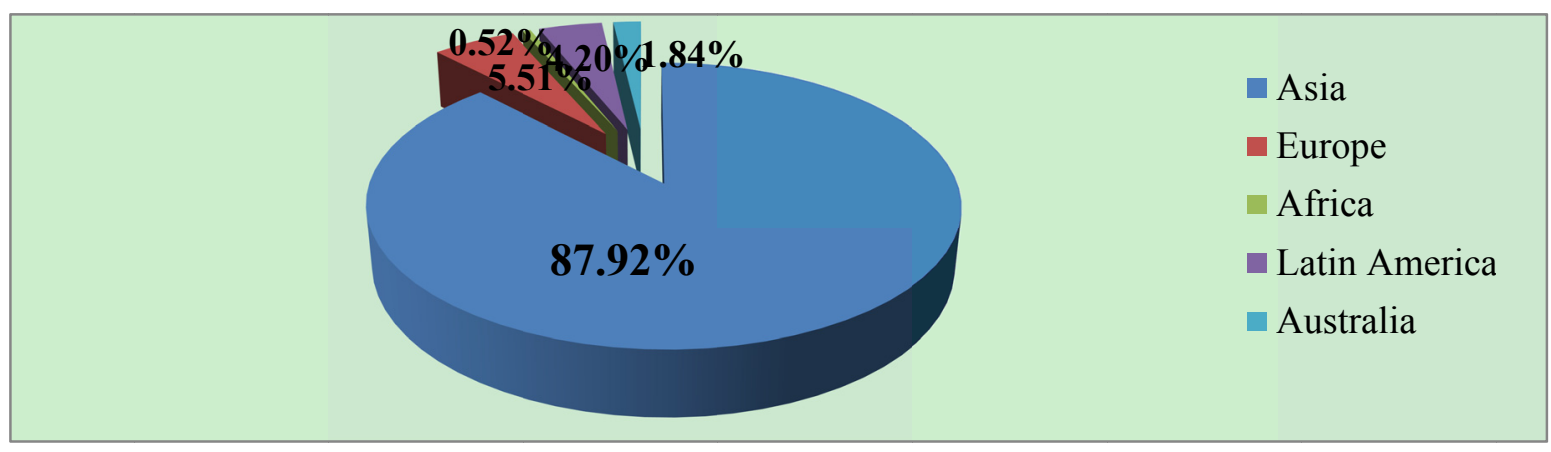

Figure 2. Continental origin of enterprises

Source: V. MoF. (2015)

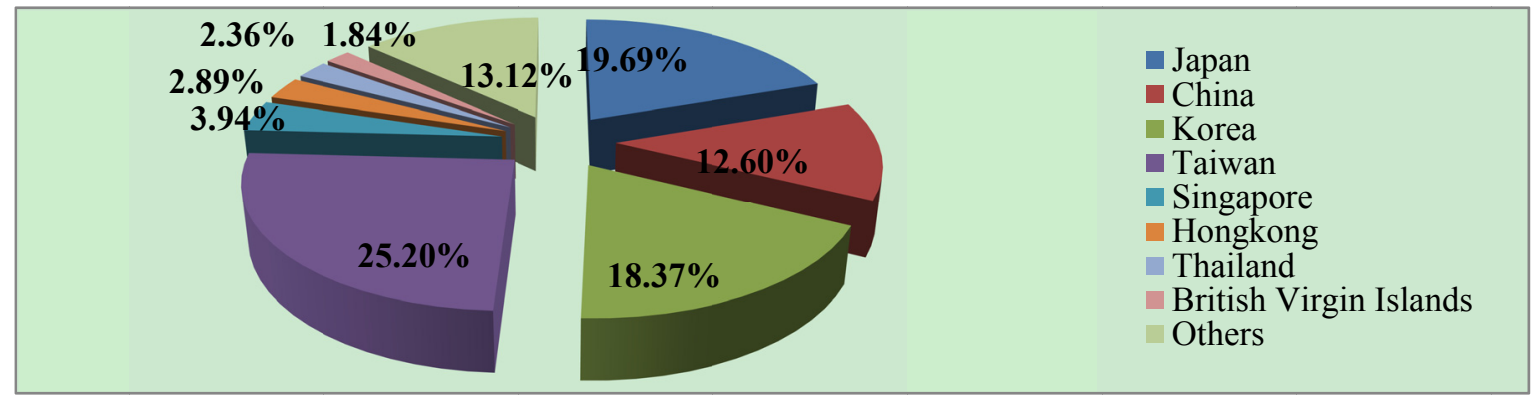

Figure 3. Nationality of FDI enterprises

Source: V. MoF. (2015)

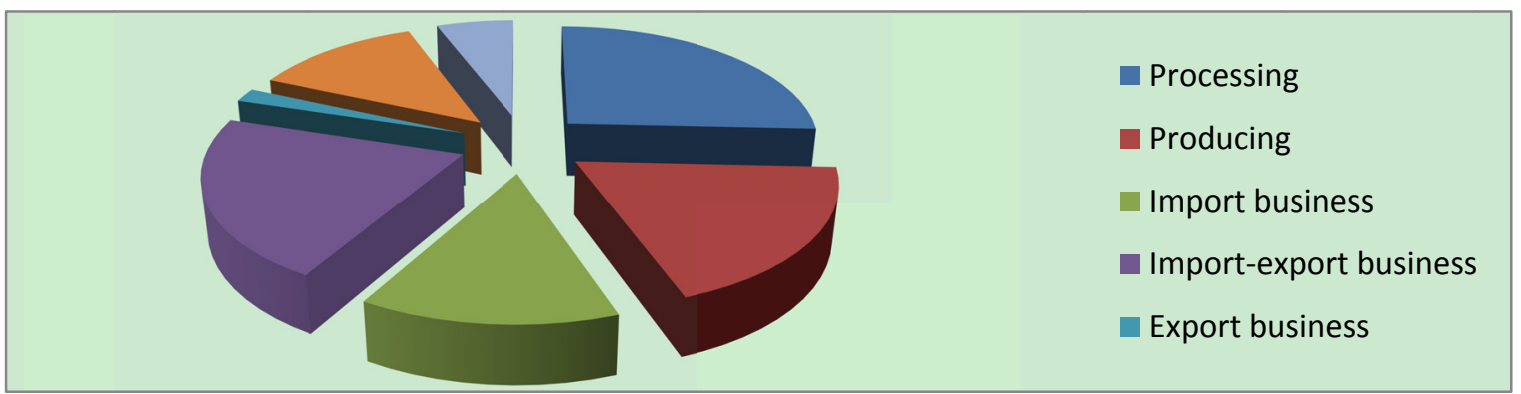

Figure 4. Business type of FDI enterprises

Source: V. MoF. (2015) 
Regarding the income tax of parent countries, $39.11 \%$ are greater than $22 \%$. The ratio of enterprises that have transaction cooperation with foreign enterprises in their activities is also high (see Figures 5 and 6).

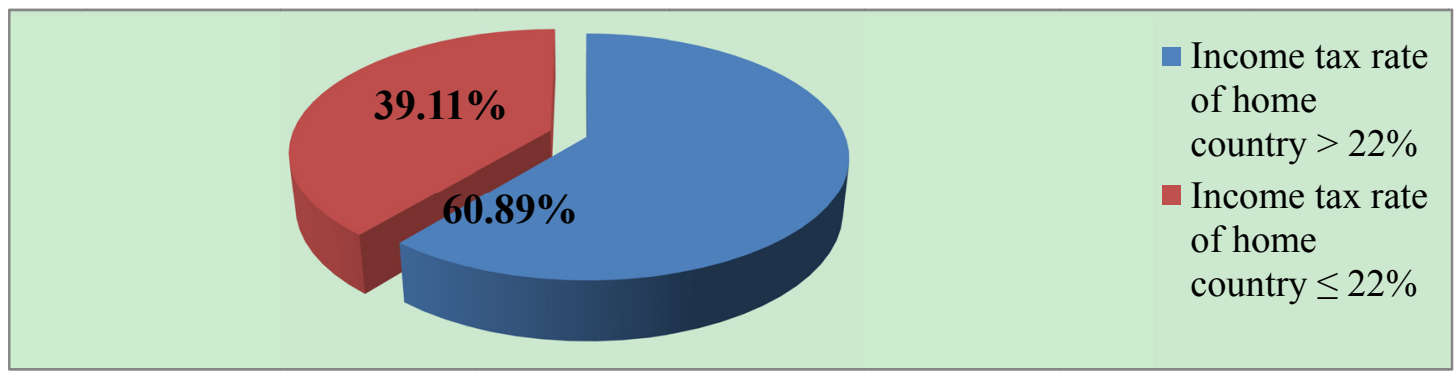

Figure 5. Proportion of parent countries' income tax rate

Source: V. MoF. (2015)

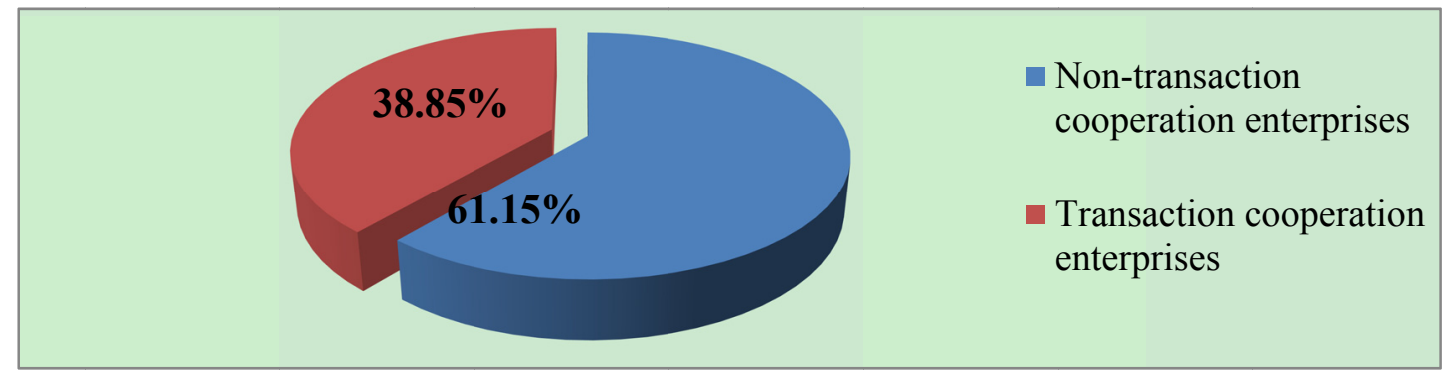

Figure 6. Proportion of enterprises' transaction cooperation

Source: V. MoF. (2015)

\subsection{The Analysis Results}

\subsubsection{Tests of the Study Model}

To analyze the relationship between the factors related to transfer pricing and the earnings of FDI enterprises, the study used regression analysis to test the hypotheses. The analysis shows that Pearson correlation coefficients have Sig. $<\alpha=0.01$, and there is no multicollinearity of independent variables. Histogram and P-P plot tests prove that normal distribution is not infringed. In addition, the autocorrelation test also demonstrates that the selected simple linear regression model is suitable (see Table 2).

Table 2. Autocorrelation

\begin{tabular}{|c|c|c|c|}
\hline \multicolumn{4}{|c|}{ Breusch-Godfrey serial correlation LM test } \\
\hline F-statistic & 1.142566 & Prob.F $(1,365)$ & 0.2858 \\
\hline Obs*R-squared & 1.188929 & Prob.Chi-square(1) & 0.2755 \\
\hline
\end{tabular}

Regarding the test of the general fit of the study model, the results show that the model has statistical significance with sig. $=0.01$ and 0.05 , and $\mathrm{R}^{2}=0.585$ is rather high (see Tables 3 and 4).

Table 3. General fit of the study model

\begin{tabular}{lcrrrc}
\hline & Sum of squares & df & Mean square & F & Sig. \\
\hline Regression & $1,477.944$ & 14 & 105.567 & 36.882 & $0.000^{\mathrm{c}}$ \\
Residual & $1,047.610$ & 366 & 2.862 & & \\
Total & $2,525.554$ & 380 & & & \\
\hline
\end{tabular}


Table 4. Result of regression analysis

\begin{tabular}{|c|c|c|c|c|c|}
\hline Independent variables & $\begin{array}{c}\text { Unstd. } \\
\beta\end{array}$ & $\begin{array}{c}\text { Std. } \\
\beta\end{array}$ & $\begin{array}{l}\text { Std. } \\
\text { error }\end{array}$ & $\begin{array}{c}\text { t- } \\
\text { Statistic }\end{array}$ & VIF \\
\hline \multicolumn{6}{|c|}{ Factors related to transfer pricing } \\
\hline $\mathrm{X}_{1}$ & $-0.494 * *$ & -0.092 & 0.215 & -2.298 & 1.406 \\
\hline $\mathrm{X}_{2}$ & $-0.394 * *$ & -0.074 & 0.206 & -1.915 & 1.318 \\
\hline $\mathrm{X}_{3}$ & $-0.516^{* *}$ & -0.065 & 0.291 & -1.775 & 1.190 \\
\hline $\mathrm{X}_{4}$ & $-0.244 * * *$ & -0.173 & 0.057 & -4.258 & 1.457 \\
\hline \multicolumn{6}{|c|}{$\begin{array}{l}\text { Factors related to the performance of FDI enterprises } \\
\text { (controls) }\end{array}$} \\
\hline $\mathrm{X}_{5}$ & $0.007 * * *$ & 0.150 & 0.002 & 3.787 & 1.376 \\
\hline $\mathrm{X}_{6}$ & $0.240 * * *$ & 0.621 & 0.015 & 15.720 & 1.378 \\
\hline $\mathrm{X}_{7}$ & $-5.656^{* * *}$ & -0.140 & 1.404 & -4.030 & 1.060 \\
\hline $\mathrm{X}_{8}$ & $3.306^{* * *}$ & 0.237 & 0.634 & 5.217 & 1.816 \\
\hline$X_{9}$ & $0.205^{* * *}$ & 0.218 & 0.042 & 4.839 & 1.791 \\
\hline Constant & -0.373 & & 0.250 & -1.489 & \\
\hline \multicolumn{6}{|l|}{ Model coefficients } \\
\hline $\begin{array}{l}\mathrm{R} \text { Squared }\left(\mathrm{R}^{2}\right)=0.585 \\
\text { Watson }=2.099\end{array}$ & $=0.569$ & urbin- & & & \\
\hline
\end{tabular}

\section{Dependent variable: $\mathrm{EBT}$ of FDI enterprises $(\mathrm{Y})$}

Signs $(* *),(* * *)$ mean significance at $5 \%, 1 \%$.

\subsubsection{Analysis of Findings}

The results show the relationship between factors in the regression:

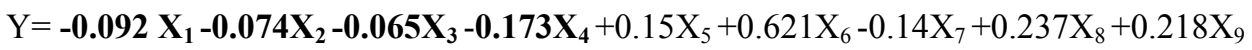

The analysis proves that nine factors have weak to moderate relationships with EBT (standardized $\beta=0.065 \div$ 0.621). Four factors related to transfer pricing have inverse relationships with enterprises' EBT. Hypotheses $\mathrm{H}_{1}$, $\mathrm{H}_{2}, \mathrm{H}_{3}$ and $\mathrm{H}_{4}$ are accepted, $\mathrm{X}_{1}$ (home countries' income tax rate), $\mathrm{X}_{2}$ (activity type), $\mathrm{X}_{3}$ (import-export cooperation ratio), and $\mathrm{X}_{4}$ (loss years) have a weak relationship with EBT $(\beta=-0.065 \div-0.173)$.

Hypotheses $\mathrm{H}_{5}$ to $\mathrm{H}_{9}$ are accepted, $\mathrm{X}_{6}$ (ROE) has a significant relationship with EBT $(\beta=0.621)$, and the rest have a moderate relationship with EBT $(\beta=0.14 \div 0.237)$.

The results show that the factors related to transfer pricing (the income tax rate of the home country; the relationship between enterprise type and import-export transactions; the ratio of import-export cooperation to the total import-exportation value; the loss years) have a relationship with the earnings of FDI enterprises; when these elements increase, EBT decreases (see Table 5). However, this relationship is rather weak. 
Table 5. Results of hypothesis testing (dependent variable: EBT)

\begin{tabular}{cccccccc}
\hline Group & Hyp. & $\begin{array}{c}\text { Ind. } \\
\text { variables }\end{array}$ & $\begin{array}{c}\text { Hypothesized } \\
\text { effect on the EBT }\end{array}$ & $\begin{array}{c}\text { Hypothesized } \\
\text { relationship with } \\
\text { EBT }\end{array}$ & $\begin{array}{c}\text { Hypothesis } \\
\text { test result }\end{array}$ & $\begin{array}{c}\text { Effect } \\
\text { result }\end{array}$ & $\begin{array}{c}\text { Rel. } \\
\text { result }\end{array}$ \\
\hline Signs of & $\mathrm{H}_{1}$ & $\mathrm{X}_{1}$ & -- & Moderate & Accepted & -- & Weak \\
transfer & $\mathrm{H}_{2}$ & $\mathrm{X}_{2}$ & -- & Moderate & Accepted & -- & Weak \\
pricing & $\mathrm{H}_{3}$ & $\mathrm{X}_{3}$ & -- & Moderate & Accepted & -- & Weak \\
& $\mathrm{H}_{4}$ & $\mathrm{X}_{4}$ & -- & Moderate & Accepted & -- & Mod. \\
\hline Control & $\mathrm{H}_{5}$ & $\mathrm{X}_{5}$ & + & Moderate & Accepted & + & Mod. \\
factors & $\mathrm{H}_{6}$ & $\mathrm{X}_{6}$ & + & Moderate & Accepted & + & Sig. \\
& $\mathrm{H}_{7}$ & $\mathrm{X}_{7}$ & -- & Moderate & Accepted & -- & Mod. \\
& $\mathrm{H}_{8}$ & $\mathrm{X}_{8}$ & + & Moderate & Accepted & + & Mod. \\
& $\mathrm{H}_{9}$ & $\mathrm{X}_{9}$ & + & Moderate & Accepted & + & Mod. \\
\hline
\end{tabular}

The five control hypotheses demonstrate the rationality of the study sample regarding the relationship between production cost, ROE, punishment cost, amount of income tax, and operation years with the enterprises' EBT.

The finding demonstrates that although there is a relationship between factors related to transfer pricing and enterprise income, it is rather weak, and its impact seems insignificant.

\section{Discussion and Proposal}

\subsection{Elements Related to Transfer Pricing}

- The income tax rate of the parent country affects the EBT of FDI enterprises in Vietnam, which is a sign of transfer pricing. The result supports the studies of Tang (1993), Grubert \& Mutti (1991), Hines \& Rice (1994), Eggert \& Winner (2010). This relationship is weak but supports the warning signs of FDI enterprises' transfer pricing. With a lower income tax in the home country, transfer pricing helps to decrease the income tax of FDI enterprises. In the case of Vietnam, not only subsidiaries of MNCs but also associated enterprises can perform transfer pricing. In such conditions, FDI enterprises can buy raw materials from cooperating enterprises in the home country at a higher price and sell its products at a lower price.

- The enterprises that have activities related to processing and the import-export of materials and services with cooperating partners can perform transfer pricing. The study also demonstrates that the ratio of import-export cooperation transactions and the loss years have a negative impact on enterprises' earnings.

These four elements are signs of transfer pricing, and when they increase, enterprises' EBT shrinks. This finding supports the consideration of the Vietnam General Department of Taxation about activities of FDI enterprises. However, their relationship coefficients $\beta$ are very small $(0.065,0.074,0.092,0.173)$, their effect on EBT is small, and naturally, the loss of income tax is negligible compared with that of other taxes.

\subsection{Control Factors}

To prove the rationality of the data for analysis, five elements are considered as controls. According to normal theory and experience, variable (production) cost, ROE, punishment cost, amount of income tax, and operation years have a relationship with EBT. When the variable cost increases, the turnover and the EBT usually increase. Normally, ROE, and income tax always have a close relationship with enterprises' earnings; when enterprises operate over many years and can survive, their earnings are usually good and stable. In addition, an enterprise that incurs much punishment from governmental organizations for its activities is often in a bad situation.

\subsection{Proposal}

The result of this research affirms that the warning of Vietnam Ministry of Finance is reasonable. The regression analysis demonstrates that there are relationships between EBT and the ratio of import-export cooperation with other foreign enterprises, the type of business, loss years and the income tax of parent countries. These elements have a relationship with transfer pricing. The results show that the negative effect of transfer pricing is not severe in Vietnam. Based on these results, this paper presents some proposals:

- A way to prevent transfer pricing is to establish a reasonable income tax; this low tax rate can prevent transfer 
pricing and encourage national revenue and FDI enterprises' profit. A low income tax rate can affect the national budget in the short term, but in the long term this policy strongly encourages tax revenue for the country.

- Vietnam's legal system is still weak in controlling transfer pricing activities. The government has to issue effective laws and regulations to better control this activity. A strong legal system can attract FDI while maintaining business equality and national income.

Recently, the Vietnamese government issued Decree No 20/2017/ND-CP (V.G. 2017) about 'Regulations on tax administration for enterprises are having associated transactions' in which it determines these important matters:

* The government assigns management responsibility about transfer pricing for seven ministries and ministerial-level agencies.

* It determines the nature of transfer pricing activities and the partners of associated transactions. The decree also regulates the declaration documents of associated activities; enterprises are exempt from making a declaration.

* The decree regulates comparison analysis methods in associated activities and price determination methods, as well as the taxation of transaction activities.

This decree represents governmental progress in transfer pricing control, clarifying transfer pricing activities. However, price comparison is difficult to apply; it can cause trouble for enterprises that conduct transaction activities without aiming for transfer pricing.

- Effectively controlling transfer pricing activities requires efficient cooperation among governmental organizations (taxation, customs, audits, state banks, etc.).

- The authorities must select high-quality and moral staff who can manage this sensitive field.

- The Vietnamese government should have good international cooperation in order to share information and experiences and to control transfer pricing.

- Management organizations should regulate the activities of FDI enterprises, discovering their transfer pricing but without hindering their normal business.

\section{Conclusion}

This research investigates the relationship between the elements related to FDI enterprises' transfer pricing and earnings and proves that while this relationship exists in Vietnam, it is not serious. This study reveals a negligible effect of transfer pricing on income tax. In addition, authorities can use the results of this study to objectively discover and estimate enterprises' transfer pricing. Although this study supports the warning of the Vietnam General Department of Taxation about the signs of transfer pricing, its negative effect is insignificant. The research shows that not only the divisions of MNCs but also FDI-associated enterprises can perform transfer pricing. However, the Vietnamese government may not officially uncover these activities. In many countries, transfer pricing has been accepted to some degree to attract foreign investment. Therefore, the government should amend unsuitable laws to resolve the problem rather than using administrative orders. Wise policy and a strong legal system can limit the negative effects of transfer pricing and continue to attract foreign investment, especially of MNCs, which are large investors that can change the economic situation of a country.

According to circular 96/2015/TT-BTC of the Ministry of Finance (V.MoF. 2015), in 2017, the income tax rate of Vietnam decreased to $20 \%$. This tax rate is lower than the tax rates of many countries, such as Japan, China, Korea, and Taiwan, which are the main foreign investors in Vietnam. In this environment, whether and how associated enterprises can engage in transfer pricing, a concerning problem in many developing countries, should be the subject of further study.

\section{References}

Bradley, F. (1991). International Transfer Pricing. New York, USA, John Wiley and Sons.

Chan, K., \& Hung, C. L. (1997). An Empirical Study of Tax Audits in China on International Transfer Pricing. Journal of Accounting and Economics, 23, 83-112. https://dx.doi.org/10.1016/S0165-4101 (96)00445-4

Choi, F. D. S., \& Mueller, G. G. (1992). International Accounting (2nd ed.). Englewood- Cliff, New Jersey, USA, Prentice Hall International Inc.

Cooper, R. V. L. (2000). Boardroom alert: Transfer pricing is the tax issue for multinational companies. Directorship, 26(2), 13-16.

Dunning, J. H. (1993). Multinational enterprises and the global economy. Boston, MA, USA, Addison Wesley 
Publishing.

Easson, A. J. (1999). Taxation of Foreign Direct Investment: An Introduction. Kluwer International, London, England.

Eden, L., \& Rodriguez, P. (2004). How weak are the signals? International price indices and multinational enterprises. Journal of International Business Study, 35(1), 61-74. https://doi.org/10.1057/palgrave.jibs.8400069

Egger, P., Eggert, W., \& Winner, H. (2010). Saving taxes through foreign plant ownership. Journal of International Economics, 81(1), 99-108. https://doi.org/10.1016/j.jinteco.2009.12.004

Ernst and Young. (2003). Transfer Pricing 2003 Global Survey. Retrieved August 15, 2017, from http://webapp01.ey.com.pl/EYP/WEB/eycom download.nsf/resources/Transfer\%20Pricing\%20Survey\%20 Report_2003.pdf/\$FILE/Transfer\%20Pricing\%20Survey\%20Report_2003.pdf

Ezejelue, A. C. (2008). A Primer on International Accounting. Aba. Nigeria, Clear print Publishing.

Garrison, R. H., \& Noreen, E. W. (2000). Managerial Accounting International Edition (9th ed.). Boston, USA: Irwin- Mac Graw Hill.

Grubert, H., \& Mutti, J. (1991). Taxes, tarrifs and transfer pricing in multinational corporation decision making. Review of Economics and Statistics, 33, 285-293. https://doi.org/10.2307/2109519

Hines, J. R. J., \& Rice, E. M. (1994). Fiscal paradise: Foreign tax havens and American business. The Quarterly Journal of Economics, 109(1), 149-182. https://doi.org/10.2307/2118431

Jensen and Schott. (2006). Transfer pricing by US Based Multinational Firms. Retrieved August 15, 2017, from http://faculty.som.yale.edu/peterschott/files/research/papers/tp_52.pdf

Johnson, W. A., \& Kirsch, R. J. (1991). International Transfer Pricing and Decision Making in United States Multinationals. International Journal of Management, 8(2), 554-561.

Kim, S. H., \& Miller, S. W. (1979). Constituents of the International Transfer Pricing Decision. Columbia Journal of World Business, 14(1), 69-77.

Li, J. (2005). International transfer pricing practices in New Zealand. University of Auckland, Business Review, $7(1), 59-65$.

Lymer, A., \& Hassedine, J. (2002). The International Taxation System. Publisher Springer US. https://doi.org/10.1007/978-1-4615-1071-0

Okoye, A. E. (2011). Cost Accountancy; Management Operational Applications (2nd ed.). Benin City, Nigeria, Midex Publishing Co. Ltd.

Okwoma, A. A. (2014). The Effects of International Transfer Pricing on Host Nations: An Overview of Developing Nations. SCSR Journal of Business Entrepreneurship, 1(1), 34-41.

Tang, R. Y. W. (1981). Multinational Transfer Pricing, Canadian and British Perspectives. Butterworth, Toronto, Canada.

Tang, R. Y. W. (1993). Transfer pricing in the 1990s: Tax and management perspectives. Westport, Connecticut, USA: Quorum Books.

V. MoF. (2015a). Vietnam Ministry of Finance. Circular 96/2015/BTC, 'Instructions about income tax of enterprises by Decree 12/2015 ND-CP'. Retrieved August 10, 2017, from http://www.mof.gov.vn/webcenter/portal/mof/r/o/policyhl/policyhl_chitiet?dDocName=MOF149123\&dID= 69393\&_afrLoop=14495506655709337\#!\%40\%40\%3F_afrLoop\%3D14495506655709337\%2

V. MoF. (2015b). Vietnam Ministry of Finance. 'Annual Report 2014'. Retrieved August 10, 2017, from www.mof.gov.vn/webcenter/ShowProperty?nodeId=/UCM56/MOF304275//...1

Vicard, V. (2015). Profit shifting through transfer pricing: evidence from French firm level trade data. Banque de France Working Paper, No 555. https://dx.doi.org/10.2139/ssrn.2614864

Vietnam General Department of Taxation. (2011). Annual report. Retrieved August 10, 2017, from http:/www.gdt.gov.vn/wps/portal/english

Vietnam Government. (2017). Decree No 20/2017/ND-CP about 'Regulations on Tax Administration for Enterprises having associated Transactions'. Retrieved August 2, 2017, from http://www.chinhphu.vn/portal/page/portal/English 


\section{Copyrights}

Copyright for this article is retained by the author(s), with first publication rights granted to the journal.

This is an open-access article distributed under the terms and conditions of the Creative Commons Attribution license (http://creativecommons.org/licenses/by/4.0/). 